\title{
LONG-TERM CHALLENGES OF ROMANIAN URBAN NETWORK: PLANNING FOR REGIONS WITH DIFFERENT BACKGROUND
}

\author{
LÁSZLÓ CSÁK \\ Babeş-Bolyai University \\ E-mail: laszlo.csak@gmail.com
}

\begin{abstract}
Romanian development policy and planning always had a major goal, namely turning Romania from a rural country into a prosperous urbanized one. Rurality is associated with backwardness, poverty and with a not really proudly accepted past. In the present paper I try to identify the main periods of Romanian planning, and I also use statistical demographic time series in order to describe the present state and the trends of urbanization in Romania. Planning, when it was applied, had a decisive effect on Romanian urbanization, while lack of planning or inappropriate planning is marked by stops in increase of urban share.
\end{abstract}

Keywords: Romania, town planning, systematization, development, five-year plans, housing, architecture

\section{Introduction}

In this essay I summarize two of my presentations: the first was held during the $33^{\text {rd }}$ György Ránki Hungarian Chair Conference entitled "Transformations of Urban Social Fabric in East Central Europe", the second one was presented to the audience of the Romanian Studies Conference at Indiana University on the same day.

The methodology I adopted is mainly based on the following pillars:

- handbooks, plans and texts on urban and town planning in Romania,

- interviews with design professionals formerly working at the state planning institutions,

- statistical data analysis. 
The texts I used were those accessible in the Central University Library Carol I in Bucharest. It seems necessary to add that it was really easy to read through these texts written during the one century history of Romanian planning: most of the texts disappeared during the several regime changes Romania had to face. I would like to also add that the librarians suggested me using new texts they have there, as they thought I choose the books by mistake. So the total list of texts accessible is quite short, and readers merely use them. I can tell that the texts I could read seem to offer a good insight in Romanian planning thought and its evolution, so I decided to put together the timeline and, based on that, I think that I could identify the major periods of planning thought in Romania. All texts are primary texts representing the corpus to be analyzed in order to describe the narratives of Romanian planning - I mention only one exception, the work of the late professor Nicolas Spulber (1971) on socialist management, one of the few books on the regime accessible in a public library before the Revolution.

The very few interviews I managed to organize (only 3 could be finalized) cannot serve as a scientific base for my text, but it really helped a lot in understanding where the authors really put the emphasis - at least during the period of systematization. All three architects I questioned used to work at the state planning institute, and they are active in design even today.

Regarding the statistical data I would like to highlight that data concerning the period before 1992 is not really reliable, so I used the primary texts I read as sources of data. After 1992 till 2014 the National Institute of Statistics (of Romania) offers a good range of quality data in time series suitable for analysis.

So the main parts of the present text are:

- identifying the main challenge for Romanian planning,

- periods of Romanian planning,

- spatial pattern and urban-rural shift (and shift back).

Why should one deal with such issues of previous periods, one may ask - and this question is relevant, indeed. But how can one understand the spatial structure of a country without any awareness of the thoughts that shaped its specificity? So my adventure seems to me even today a worthy one.

\section{Town planning in Romania: network or system}

Romania in its present form was established in 1918, right after the World War I - it had to face only slight modifications, like the annexation of a part of Moldova by the USSR. None of its territories were developed in that time, even if the 
main railway lines of today had been already built, and not too much development occurred in the last century in this respect (Biji, 1964).

The urban network was already present: today's main cities were several thousand inhabitant towns even in the past. The new towns later established by the communist party, like Gheorghe Gheorghiu-Dej (today Onești), Victoria, Motru or Doctor Petru Groza (today Ștei) did not challenge historical regional poles, and they did not have any scope like that.

If one looks at texts on planning, it seems clear that every era had its objective and teleology regarding towns. Towns are very much associated with prosperity, culture, development, growth, quality jobs, healthy spaces, good housing, and utilities in the Romanian planning thought. If one looks at the very much underdeveloped (and not just lagging behind) rural areas of Romania, it is clear why planners and policy makers looked at the urban as the savior of Romania - and in 1912 only 16,4 per cent of the population lived in urban settlements.

In a very much rural and underdeveloped country how can one talk about planners? The first planner in Romania was Cincinat Sfințescu (Sfințescu, 1919), who worked for the city hall of Bucharest, activated in the land registry department. Sfințescu had the opportunity to work on the first plan of Bucharest titled Plan General de Sistematizare al capitalei (General systematization plan of the capital). Sfințescu had to choose between two major European trends: Howard's Garden city movement on the one hand, and on the other hand the Haussmannian order that reshaped Paris and some main cities like Budapest. In 1919 Sfințescu decided to suggest the garden city concept instead of the Haussmannian. His work seems really detailed: he dealt with the questions of transport, utilities, housing. He analyzed the population growth trend and assumed a one million inhabitant Bucharest in 1980. Sfinţescu studied how to design the tramway network of Bucharest, and based on the unfortunate results of the Budapest underground, dismissed the idea of this kind of infrastructure in the case of Bucharest.

Sfințescu's dream could not become reality: the structure of Bucharest was rapidly changing, his plan was never put into practice, and in 1934 a new plan (Marcu, Bolomey, 1934) was formulated and approved by a new team of urban planners - it is worth remarking that in less than two decades after the early bird Sfințescu, there was plenty of planners and even the Urban Planning Institute of Romania were functioning (Davidescu, 1937). But the main motor of change was economic growth, and as its consequence: wealthy classes wanted to live like in Paris. So the Howard-Haussmann match was over and Haussmannian approach was present everywhere - even if the city hall never had enough sources to build the streets and boulevards projected by the team of the Urban Planning Institute of Romania.

The character of Bucharest had changed, and the quarters that could fit into Ottoman Empire towns, the so-called mahalas (Stahl, 1910) were ruined once and 
forever - Henric Stahl even started a project in order to conserve the memory of the picturesque city they loved by means of photo archive. So what was done had nothing in common with Romanian tradition, and even if urban planners had an unquestionable goodwill, the outcome was a partly realized Haussmannian torso instead of the Howardian garden city.

During the period between the two World Wars Romania was set on the track of rapid modernization, so Bucharest was called the little Paris by admirers of the city, but World War II put an end to any positive expectation countrywide. In the late 1930s most of the texts I could access reflected the admiration of Nazi ideology (clear and proud antisemitism, racism), anti-Hungarian outbursts (very much understandable in the context of the harbingers of the Second Vienna Award when Hungary gained back 43,492 $\mathrm{km}^{2}$ of its former territory from Romania) (Muresanu, 1934, Manoilescu, 1938), and at the same time the five year plan of the USSR. I could not find any reference to the German Raumordnung, which is a bit grotesque because Romania was involved in World War II on the side of Germany, against the USSR.

After World War II the communists came to power and a soviet type economic development path was followed: heavy industry, urbanization, massive investments in infrastructure in order to show the victory of ideology even over the nature itself (Spulber, 1971). The five year plans were also introduced. This period lasted until the 1989 revolution that forced the fall of communism in Romania. Planning was crucial, as it was advertised in anti-communist texts written on Romania (for instance: Giurescu, 1994). What was the main objective of these plans? Infrastructure and industry were only the means: they aimed at urbanization of Romania. So the telos remained the same: a heavily rural country was supposed to catch up to the Occident, or using the words of that time, building a multilaterally developed country with omni-competence (Spulber, 1971), for the working classes and for agricultural workers.

One can imagine that Howardian utopia and Haussmannian business was put aside and an adaptation of Corbusierian architectural ideology was put into practice. But the task was so enormous: in 1948 only 23,4 per cent of the population lived in urban settlements, the rest lived in villages with no utilities at all, with lack of accessibility, in poverty, lack of basic public services, no work places. And the urban settlements had to change their character at the same time: their patterns were not fashionable for Stalinist urban planning, and their historical centers were named 'feudal' centers (Laurian, 1962, Curiuschi, 1967, Lazarescu, Ciobotaru, Cristea, 1977). They did tear down whole neighborhoods in several cases, but there was also an intention of conserving built heritage, even if they were aware that ideologically speaking the heritage cannot serve as a form for the new communist content (Lazaraescu, Cibotaru, Cristea, 1977): realized examples are Deva, Brăila, Tîrgu Mureș or Sighișoara or Suceava. 
What could be seen from outside was a massive demolition of whole neighborhoods in Bucharest and also in other 36 cities in Romania (Giurescu, 1994), officially called systematization of the national territory (Cucu, 1977, Matei, 1977). All settlements, no matter urban or rural, had to find their place in the hierarchical and dynamic urban system. I would like to underline that planners looked at the layout of phenomena as a system, opposed to the network they wanted to abolish. The system was supposed to be scientifically and ideologically grounded. So those settlements that could not fit into the system were declared ready for dezafectare (decommissioning), while those with outdated or not enough efficient structure for asanare (sanitation) (Cardas et al., 1983, Lazarescu, Ciobotaru, Cristea, 1977).

The outcome became robust after implementing the Law on systematization (Law no. 58 from 1974): private ownership of low quality dwellings was replaced by state owned blocks of flats offering comfort, services and utilities to a large number of people. A similar trend was present also during the urbanization or systematization of rural communes, where some small scale apartments blocks investment was realized, education, health care, cultural and commercial infrastructure was introduced - mainly on the plots formerly used by private dwellings. This process was often accused as inhuman and destroying. In my understanding the systematization of the communist era really changed the character of Romanian cities and villages, but without these large scale investments one could not fight poverty and deprivation. Acting against Romania's rurality was present from the very beginning (Botis, 1941), and it was one of the motors of destroying the mahalas from the 1910s to the early 1930s - but the state in the communist era had much more power and sources to fulfill the urbanization project.

I am not willing to say that the first period of Romanian planning was similar or there are continuities: there were serious ideological incompatibilities between the quasi-haussmannian interbelic (interwar) period and the 1947-1989 one: Marxism and Leninism, scientific socialism was something completely different, but the aim remained the same - urbanization of Romania.

The spatial utopia they wanted to realize was a spatially balanced system, with small level of concentration: in this context also small towns with only a couple of thousands of inhabitants received state investment in heavy industry, the road and rail network was modernized, and those villages with sufficient development potential received funds too.

Nevertheless, the population had very bad feelings about systematization, and intellectuals had similar thoughts too, so right on the eve of the Revolution the Frontul Salvării Naționale (National Salvation Front) in its first decree repealed all the laws referring to systematization, and in this context the new age started with no planning or building regulation at all. The no plan era lasted until 2001 
when the current planning law was adopted - they had to find a new name for systematization, so they call it now amenajarea teritoriului (which can be translated to English as territorial planning, it is originated from the French aménagement du territoire). I am going to enter into more detail about it in the next part of the paper, but I think I can conclude here by identifying the periods of Romanian planning as follows:

1) the rise of planning (Haussmannian and Howardian plans) from the 1910s to the early 1930s,

2) first no-planning and development period from the late 1930s to 1947,

3) communist systematization and urbanization from 1947 to 1989,

4) second no-planning and development period from 1989 to 2001,

5) new planning in the context of the European Union from 2001 to present.

\section{Spatial Pattern of Population Change}

The main criticism against the systematization planning period was that it had negative impact on rural settlements both physically and socially speaking - even if there were serious works on the theory and practice on what we now may call public participation (Stahl, Sebestyén, 1972, Gusti, 1974). Perhaps it was true, but one might ask what happened after the Revolution with rural Romania? Since 1984-1985 more than half of the population lives in urban settlements: impressive success concerning the long lasting challenge: from 16,3 per cent to more than 50 per cent. The task was fulfilled by massive investment in housing, services and industry, as I have already mentioned (Lazarescu, Ciobotaru, Cristea, 1977, Monda, 1965, Sasarman, 1979). The present period started in 2001 has no other means than declaring villages as towns - the economic downturn and the political change could not let the Romanian state dispose of financial sources at least comparable to the pre-1989 times. The main source of investment in rural (and also urban) public infrastructure comes from the European Union's Funds, but it is very much questionable if it is spent in line with official planning and development policies, so it seems necessary looking at the trends using population change time series.

The first set of figures represent the situation of rural communes in the counties characterized by major cities, regional poles. I selected for this paper Cluj, Iași and Timiș in order to find out if the sort of rural Romania had turned better after abolishing the systematization. Unfortunately it is clear from the figure that the pattern in every area shows that growth and prosperity can be felt only in the very proximity of major cities: the average is only $16 \mathrm{~km}$, even if one takes into account the capital city Bucharest. The area includes the cities 
themselves and their rural hinterland with population growth. As there were no investments in the development of rural settlements, the answer seems easy to be formulated: rural Romania had to suffer once again after the Revolution: ageing population, lack of economic opportunities, amortization of public services, high fares of public transport equals rural depopulation - and I would like to highlight that it is valid not just for those villages selected previously for 'decommissioning', but there are no villages with serious population loss within $16 \mathrm{~km}$ reach from city centers, and a vast number of villages are facing the depopulation issue.
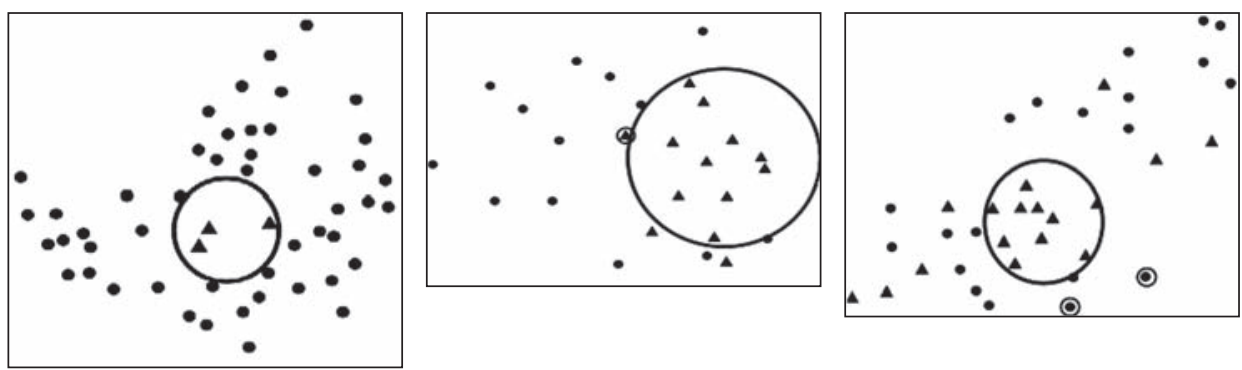

Legend: rural municipality with serious population loss

(-) declared town with population growth

A rural municipality with population growth

$\Theta$ declared town with population growth

$\bigcirc$ radius of urban influence

\begin{tabular}{|c|c|c|}
\hline Cluj area & Iași area & Timiş area \\
\hline $\begin{array}{l}16 \mathrm{~km} \text { radius urban zone } \\
\text { high GDP growth } \\
320,000 \text { inhabitant city } \\
\text { clear pattern }\end{array}$ & $\begin{array}{l}24 \mathrm{~km} \text { radius } \\
\text { low GDP growth } \\
350,000 \text { inhabitant city } \\
\text { pattern influenced by state border } \\
\text { on the East }\end{array}$ & $\begin{array}{l}18 \mathrm{~km} \text { radius } \\
\text { high GDP growth } \\
330,000 \text { inhabitant city } \\
\text { not that contoured pattern }\end{array}$ \\
\hline
\end{tabular}

Figure 1. Rural population change in urban context

The trend is not as simple as at first might seem: in some cases even towns must face population change. In Figure nr. 2 I tried to show how certain towns changed in terms of population. In some cases, there is population increase in the proximity of cities: Braşov, Bucharest and Constanța are good examples for that. Urban population loss can be observed in the South (on the bank of the river Danube), in the North (on the border with Ukraine and Republic of Moldova), and in mountainous areas. 
There is no population growth in some urban areas in towns, while it is observed in other cases? Yes, but it is easy to tell why: Bucharest and Constanța are the exceptions: in these urban areas former villages were declared as towns, so their growth is reflected in Figure nr. 2, while in most of the cases rural settlements held the status of rural communes, so they are indicated in Figure nr. 1 as villages with high population growth. Perhaps it is not easy to identify the boundary between urban and rural in Romania, that makes any comprehensive development policy quite hard to be fit to reality.

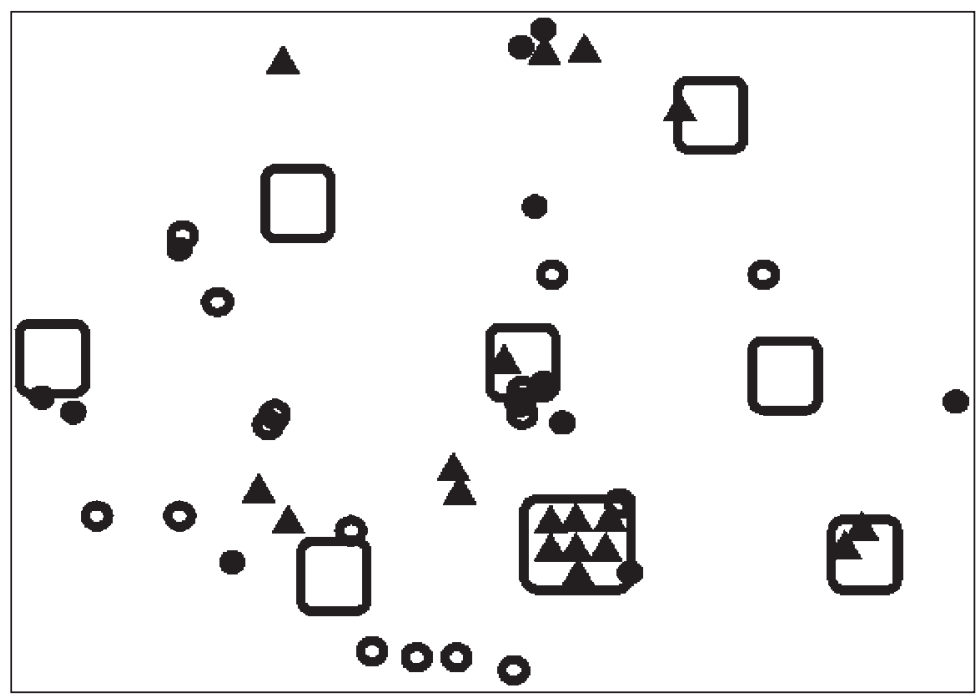

Legend: serious population loss (more than 20\%)

population loss (between $15 \%$ and $20 \%$ )

population growth (more than $20 \%$ )

urban area

Figure 2. Urban population change

Based in Figures nr. 1 and nr. 2 we can state that population growth is present overwhelmingly in urban areas, no matter what the ranking of the settlement is as defined by the law. In this respect I might also add that the issue of high population growth villages is the same as those towns around cities, so they are part of the urban development picture and no serious development policy can include them in rural development. The bad news is that in the programming period between 2014 and 2020 Romania gave priority to those rural settlements with high 
growth potential, namely to those rural communes that were not declared towns but are placed in the proximity of over 100,000 inhabitant cities. For instance the commune of Florești with nearly 23,000 inhabitants could be ranked in the upper third or top 100 of towns, but legally speaking it is made of villages and it is a rural commune.

So there are new towns in Romania, some of them declared after 2001 implementing the new law on territorial development. One can find 54 new towns on the map, all declared after 2001, but the era before 1989 was well known for rapid and forced urbanization. Between 1948 and 1978 the number of towns increased by $84-2.4$ a year, while between 2001 and 2014 the figure is 3.8 a year. If we look at Figure nr. 3 it is clear that new towns are located in areas without urban centers, mostly far from major cities. So in this context there are three different ways of urbanization in Romania:

1) new towns in areas characterized by lack of urban settlements,

2) former rural communes in the proximity of regional poles,

3) de facto towns in the proximity of regional poles pretending they are rural.

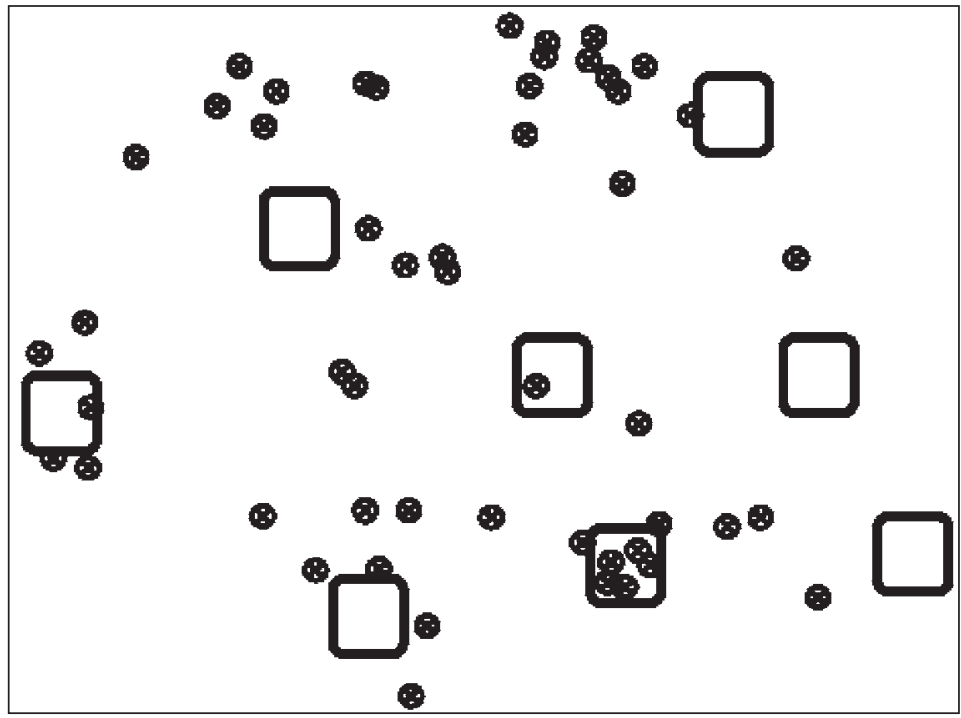

Legend: 8 new town

$\square$ urban area

Figure 3. New towns (2001-2014) 
I would like to add wo more points to the analysis: firstly I would like to show that the size of the town does not affect its population change, or at least only in the case of those micro towns with only a couple of thousand inhabitants, secondly it seems now necessary to determine whether the urbanization in terms of increasing urban share is an ongoing trend.

If we take a look at Figure nr. 4 we can conclude that over 40 per cent population growth never occurs in the case of micro towns, and micro towns are more apt for population decrease than small towns or cities. As a result of this population change is firstly influenced by the proximity of major cities or regional poles, or by their absence. The good news is that Romania has a polycentric urban network as a result of the balanced spatial idea of the era when they understood the urban network as a system, while the main issue is that these areas of growth only cover 2.7 per cent of the national territory. That means that there is a polycentric polarization going on that cannot be solved by restricted planning and development tools and sources.

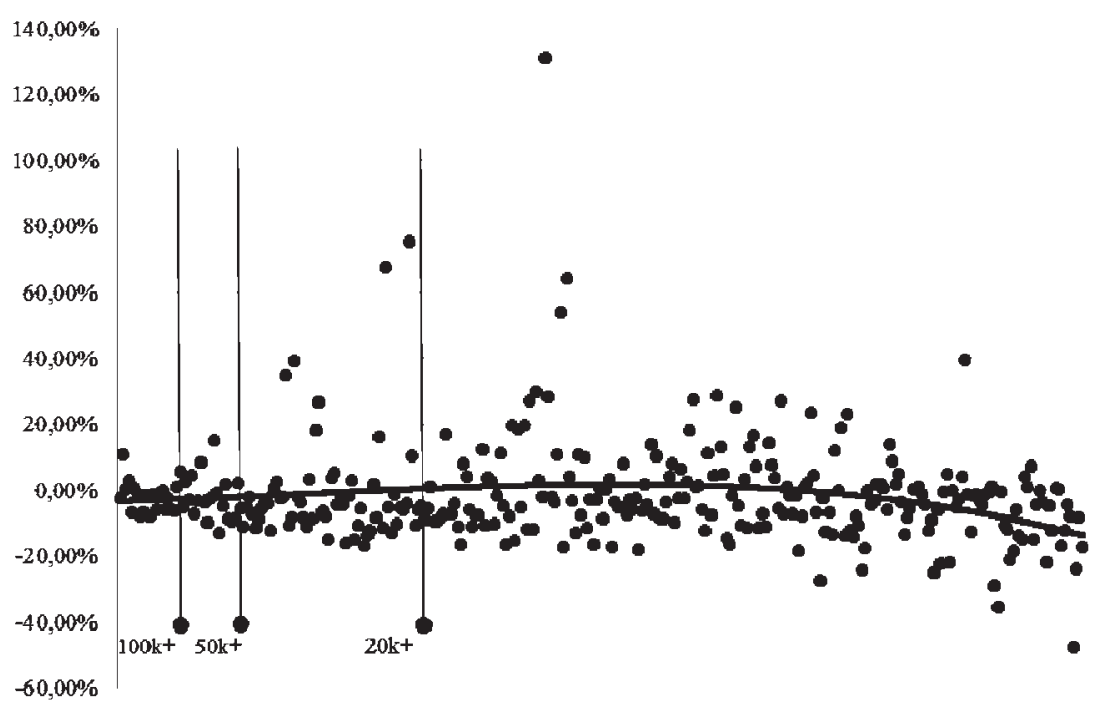

Figure 4. Population change and size (1992-2014)

I have already shown that the number of towns was growing between 2001 and 2014 in an unprecedented measure, foregoing even the first period of systematization between 1948 and 1978. In this context I calculated the figures for the next chart in order to find out if the overall aim of Romanian development and 
planning, namely the urbanization project is an ongoing one, or it has reached its climax. For the time series after 1992 I included in the urban side all settlements which are considered as urban in 2014. Please bear in mind that the number of towns grew between 2001 and 2014 by 54. Surprisingly the trendline of urban share turns negative in 2002, the function has its inflection point there. So after a century of struggling with rurality, investing enormous efforts and sources into urbanization, it seems that the project is ended - and this fact must have serious consequences on the future of Romanian planning and development, no matter urban or rural.

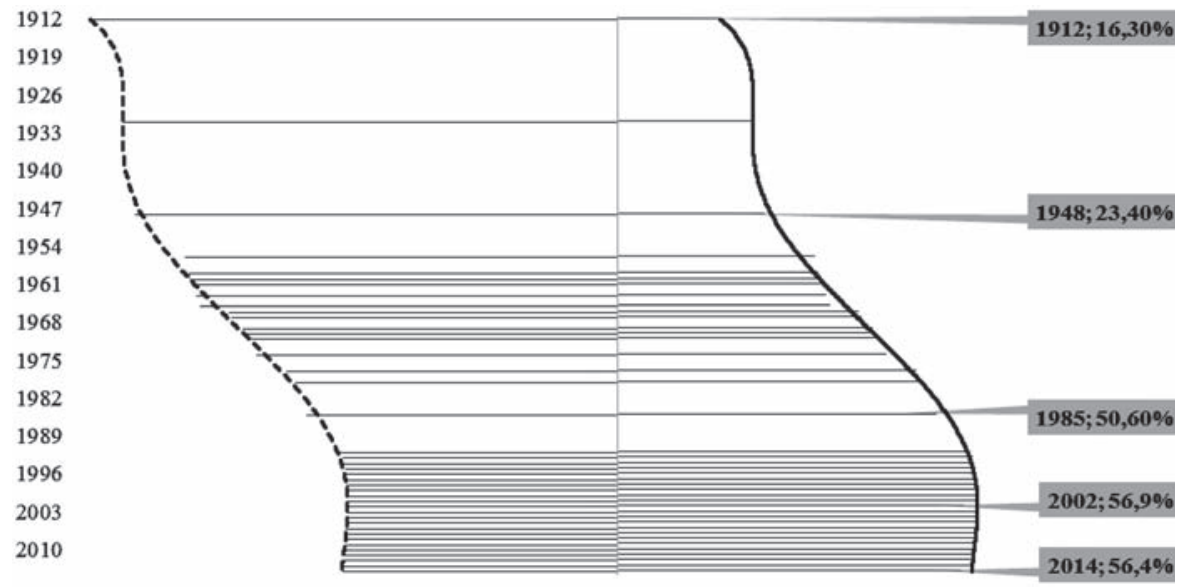

Figure 5. Urban share (1912-2014)

One more result that can be obtained by analyzing the data presented in Figure nr. 5 is that the trendline follows exactly the periods I identified before. The first two periods are characterized by the rise of urban planning but with no means of realizing its goals. The era of systematization is marked with rapid urbanization: new towns and fast population growth in existing towns. After the revolution there are no sufficient tools in order to realize any policy - there was none between 1989 and 2001, while there is a highly questionable and ineffective one currently. The failure of the post-2001 urban policy is that Romania's overarching objective of increasing urban share reached its inflection point right in 2001 when the new policy was adopted and entered into force. 


\section{References}

Biji, Mircea et al., 1964. Dezvoltarea economica a Rominiei 1944-1964. Bucharest: Editura Academiei Republicii Populare romine.

Botis, Emil. 1941. Urbanizarea tanarului roman. Timisoara: Primaria Municipiului Timisoara.

Cardas, Mircea, Bucur, Mircea, Ciricas, Gheorghe, Dina, Mircea, Ghederiu, Alexandru, Grinberg, Boris, Pavloff, Mircea, Pirvu, Ecaterina, Pop, Adriana and Rau, Romeo, 1983. Mic lexicon ilustrat al notiunilor de sistematizare. Bucharest: Editura Tehnica.

Cucu, Vasile. 1977. Sistematizarea teritoriului si localitatilor din Romania. Bucharest: Editura stiintifica si enciclopedica.

Curiuschi, Gheorghe. 1967. Centrele istorice ale oraselor. Bucharest: Editura Tehnica.

Davidescu, Ion Alexandru. 1937. Notiuni de Urbanism. Bucharest: Institutul Urbanistic al Romaniei.

Giurescu, Dinu C. 1994. Distrugerea trecutului Romaniei. Bucharest: Museion.

Gusti, Gustav. 1974. Forme noi de asezare. Studiu prospective de sistematizare macroteritoriala. Bucharest: Editura Tehnica.

Laurian, Radu. 1962. Problemele de estetica oraselor. Bucharest: Editura Tehnica.

Lazarescu, Cezar, Cibotaru, Ioan and Cristea, Doina. 1977. Urbanismul in Romania. Bucharest: Editura Tehnica.

Manoilescu, Mihail. 1938. Ideia de plan economic national. Bucharest: Asociatia Generala a Inginerilor din Romania.

Marcu, Duliu and Bolomey, Roger. 1934. Plan director de sistematizare al Municipiului Bucuresti. Memoriu justificativ. Bucharest: Editura Institutului Urbanistic al Romaniei.

Matei, Mioara and Matei, Ioan. 1977. Sociologie si sitematizare in procesele de dezvoltare. Bucharest: Editura Tehnica.

Monda, Jean. 1965. Arhitectura noua in RPR. Bucharest: Editura Stiintifica.

Muresanu, Aurel. 1934: Problemele economico-cosiale spre Planul quinquenal al Romaniei-Mari 1935-1940. Turda: Tipografia J. Füssy.

Negulescu, Ana-Eugenia. 1990. Sistematizare si urbanism, amenajari si retele utilitare, transport orasenesc: date si informatii. Bucharest: Institutul National de Informare si Documentare.

Sasarman, Gheorghe. 1979. Functiune, spatiu, arhitectura. Bucharest: Meridiane.

Sfintescu, Cincinat. 1919. Studiu asupra Planului General de Sistematizare al capitalei urmat de un antreproect de lege asupra stabilirei, construirei, desvoltarei si sistematizarei comunelor. Bucharest: Tipografia ”Jockey-Club” Ion C. Vacarescu.

Spulber, Nicolas. 1971. Socialist Management and Planning. Topics in Comparative Socialist Economics. Bloomington: Indiana University Press.

Stahl, Henri H. and Sebestyén, Gheorghe. 1972. Urbanism: sociologie, psihologie, economie. Bucharest: Centrul de Informare si Documentare în Stiintele Sociale si Politice.

Stahl, Henric. 1910. Bucuresti ce se duc. Valenii-de-Munte: Tipografia Neamului Romanesc. 